\title{
DIAGNOSTIC TESTS FOR AMOEBIC LIVER ABSCESS: COMPARISON OF ENZYME - LINKED IMMUNOSORBENT ASSAY (ELISA) AND COUNTERIMMUNOELECTROPHORESIS (CIE)
}

\author{
Marcos I. Restrepo, Zoraida Restrepo, Consuelo López Elsa Villareal, \\ Aura Aguirre and Marcos Restrepo
}

\begin{abstract}
The liter abscess is the most frequent extraintestinal complication of intestinal amoebiasis: its diagnosis is suggested by the clinical picture but it must be confirmed by paraclinic tests. Themost stringent diagnosis requires identification of $\mathrm{E}$. histolytica. But this is possible only in a feu' cases. Serological tests greatly improve the diagnosis of this severe complication of amoebiasis. We compared the Enzyme Linfed Immunosorbent Assay and the Counterimmunoeletropboresis techniques. Botb techniques were used to detect amoebic antibodies in 50 control patients, 30 patients with liver abscess and 30 patients with intestinal amoebiasis. All the sera from control patients gave negative results in both techniques. When analysing the sera from patients with intestinal amoebiasis, $10 \%$ of them were positive by ELISA but non by CIE. The sera of patients with liter abscess, we found that $90 \%$ were positive by the ELISA method and $66.6 \%$ by the CIE technique. In patients with amoebic liver abscess, the results showed that the ELISA was more sensitive than the CIE, as it presented a bigher sensitivity (100\%) than that of the CIE technique (66\%).
\end{abstract}

Key-words: Amoebic liter abscess. Diagnosis, ELISA. CIE.

Amoebiasis is an infection caused by Entamoeba bistolytica, an intestinal protozoan pathogenic for humans ${ }^{17}$. It is commonly found in tropical countries, specially in underdeveloped ones where sanitation and hygiene are deficient $t^{3}$.

It is believed that 2 to $50 \%$ of the world's population and $12.1 \%$ of Colombia population according to the second Colombian National Morbidity Survey is infected by Entamoeba bistolytica ${ }^{3}$. The parasite colonises the intestinal tract and form here it spreads to other organs, depending on its invasive capacities $^{38}$.

Amoebic infection is considered to be third most important cause of parasite-related deaths in the world, after malaria and schistosomiasis ${ }^{16}$. The most frequent extraintestinal complication of amoebic infection is the invasion of the liver by the parasite, a condition known as amoebic liver abscess.

Instituto Nacional de Salud (INS) and Instituto Colombiano de Medicina Tropical, Medellín, Colombia.

Address to: Dr. Marcos I. Restrepo, Instituto Colombiano de Medicina Tropical. PO Box 52162, Medellín, Colombia.

Fax (574) 262-5508.

Recebido para publicacão em 20/02/95.
The diagnosis of amoebic abcess is suggested by clinical features, but further paraclinic tests are required in order to identify the lesion in the liver: Ultrasonography, Computarised Tomography, Isotopic Scan, Magnetic Resonance Imaging, diagnostic aspiration, liver biopsy and surgical explorating are employed. Liver biopsy and diagnostic aspiration are, however, the methods that allow identification of $E$. histolytica in the necrotic material of the abscess or in liver tissue ${ }^{210}$. This method is the most specific of all and provides a differential diagnosis with pyogenic liver abscess, a condition which requires cultured identification of the causative bacteria ${ }^{2}$. Since the identification of E. bistolytica is feasible only in very few case, serological techniques that could help in the diagnosis of amoebic liver abscess have been implemented. They all evaluate the individual's immunological response detecting circulating immune complexes or detecting antibodies in the serum by a diversity of serological tests $s^{5718}$.

Our study evaluates the diagnostic sensitivity of two serological tests: Counterimmunoelectrophoresis (CIE) and Enzyme Linked Immunosorbent Assay (ELISA) 
Restrepo MI, Restrepo Z, Villareal CLE, Aguirre A, Restrepo M. Diagnostic tests for amoebic liver abscess: comparison of enzyme-linked immunosorbent assay (ELISA) and counterimmunoelectrophoresis (CIE). Revista da Sociedade Brasileira de Medicina Tropical 29:27-32, jan-fev, 1996.

\section{MATERIAL AND METHODS}

Study population. This population was composed by 110 patients which were distributed in 3 groups as follows:

a) 30 patients with symptomatic intestinal amoebiasis without acute dysentery, all confirmed by the presence of $E$. bistolytica cysts or trophozoites in microscopical stool examination.

b) 50 control patients, aymptomatic presumably healthy persons; with no recent or past medical history of amoebic infection in the last 2 years, and 3 negative stool examination on 3 different days.

c) 30 patients with suspected amoebic liver abscess as suggested by clinical features and ultrasonographic findings.

Blood samples were obtanide from all patients in $10 \mathrm{ml}$ tubes with no anticoagulant, to obtain serum and this was stored at $-20^{\circ} \mathrm{C}$ until serological testing.

CIE technique. This HM1 clone of $E$. bistolytica strain (obtained from Instituo Nacional de Salud - INS, Bogotá, Colombia) was cultured in the axenic BIS-33 medium of Diamond ${ }^{i}$, and then we obtained a purified antigen as described by Gandhi et al ${ }^{6}$. The CIE test used purified antigen of $E$. histolytica placed in the righ column wells and problem serum in the left column wells. Electrophoresis was run in barbital buffer ( $\mathrm{pH} \mathrm{8.6)} \mathrm{for} 45 \mathrm{~min}$ in a chamber at a constant voltage of 110 to 140 volts and 4 to 8 milliampers. The slide was incubated at $37^{\circ} \mathrm{C}$ until completely dry. The presence of a precipitin line between the antigen and serum wells was interpreted as a positive reaction ${ }^{13}$.

ELISA technique. The antigen was prepared from cultures of $E$. bistolytica clone strain HM1, grown axenically' medium TYIS-33. Harvested trophozoites were washed 3 times with saline. Then we applied the method recommended by Gandhi et $\mathrm{ll}^{\circ}$ to obtain the antigen. The trophozoites were frozen once and thawed, sonicated for 5 minutes at 20 kilocycles. Finally centrifuged at $10.000 \mathrm{x} g$ for 30 minutes at $4^{\circ} \mathrm{C}$. We used the clear supernatant as antigen with a pure protein concentration of $6 \mathrm{mg} / \mathrm{ml}$. This antigen was distributed in 100 microliter aliquots to each well of the polysturene microplates (Dynatech (R)), incubated overnight at $40 \mathrm{C}$ in a moist chamber. The microplates was rinsed with Tween-20 in PBS for 3 minutes, three consecutive times; 200 microliter of casein $(\mathrm{w} / \mathrm{v})$ in PBS were added to each well and afterwards the microplate was incubated for 1 hour at $37^{\circ} \mathrm{C}$ in a moist chamber. The plate was rinsed again with PBS-Tween 20 before adding 100 microliters of serum diluted $1 / 100$ in PBSTween 20 ; then incubated for 1 hour at $37^{\circ} \mathrm{C}$ and rinsed again. Next step, 100 microliters of conjugate anti-human IgG peroxidase (Sigma (R)) was used at a dilution of $1: 400$ in $0.1 \mathrm{M}$ PBS, $\mathrm{pH} 7.2$. The microplate was incubated at $37^{\circ} \mathrm{C}$ in a moist chamber for 1 hour. Finally, 100 microliters of substrate $(0.4 \mathrm{mg}$ of $\mathrm{o}$ phenylene diamine per $\mathrm{ml}$ of $0.1 \mathrm{M}$ phosphate citrate buffer, $\mathrm{pH}$ 5.0) were added to each well left to rest for 20 minutes in the dark. The enzyme reaction was stopped by the addition of 50 microliters of HCL $2.5 \mathrm{~N}$.

Readings were performed with a $492 \mathrm{~nm}$ filter to determine 2 optical densities (O.D.) per partient and from these, an average of O.D. values were calculated: three negative and two positive control sera were additionally processed $^{1+}$.

We are using as the Gold Standards the parasitological diagnosis of intestinal amoebiasis in the stools and ultrasonographic findigns for amoebic liver abscess.

The average cut-off point of the ELISA technique was 0.156 , the absorbance reading needed to differenciate between positive and negative samples was established by calculating the mean value plus S.D. $(p<0.05)$ of the absorbance values of samples of healthy patients, amoebiasis intestinal patient and those patients with amoebic liver abscess.

Determination of test parameters were determined using a $2 \times 2$ contingency table that included the following calculations: for sensitivity ( $S$ ): $a / a+c ; a)$ true positives, is the number of patients with parasitological diagnosis of intestinal amoebiasis and positive serological test; b) false positives corresponded to healthy asymptomatic persons without parasites in the stools (control group) but positive serological test. For specificity $(E): \mathrm{d} / \mathrm{b}+\mathrm{d}$; d) true negatives, is healthy persons without amoebiasis and negative serological test; and c) false negatives, the poatients with intestinal amoebiasis and negative serological test. For positive predictive value (PPV): $a / a+b$ and negative 
Restrepo MI, Restrepo Z, Villareal CLE, Aguime A, Restrepo M. Diagnostic tests for amoebic liver abscess: comparison of enzyme-linked immunosorbent assay (ELISA) and counterimmunoelectrophoresis (CIE). Revista da Sociedade Brasileira de Medicina Tropical 29:27-32, jan-fev, 1996.

predictive value (NPV): $d / c+d$. The calculation was applied for both ELISA and CIE tests.

\section{RESULTS}

From the 30 patients with intestinal amoebiasis, three presented positive ELISA test, but all of them were negative in the CIE test (Tables 1 and 2). None of the 50 sera from control patients gave positive results in the two tests used (Tables 1 and 2).

In patients with intestinal amoebiasis, the sensitivity of the ELISA technique rvas only
$10 \%$ but its specificity was $100 \%$ (Table 3 ). The CIE test was never found to be positive in this clinical form of amoebiasis. Only 3 sera from patients with symptomatic intestinal amoebiasis without dysentery were positive by ELISA. The predictive values of positive test were $100 \%$ for ELISA and $0 \%$ for CIE. The predictive values of negative test was $65 \%$ for ELISA and $62.5 \%$ for CIE (Table 3 ).

In the group of patients with liver abscess, $27(90 \%)$ out of 30 were positive by ELISA and $20(66.6 \%)$ by CIE (Tables 1 and 2 ). The

Table 1 - Results of the EIISA test in the diagnosts of liver abscess and intestinal amoebiasis.

\begin{tabular}{|c|c|c|c|c|c|}
\hline \multirow[b]{2}{*}{ Clinical form } & \multirow[b]{2}{*}{$\mathrm{Nr}$ of patients } & \multicolumn{4}{|c|}{ Results } \\
\hline & & negative & cases & positive & cases \\
\hline & & $\mathrm{n}$ & $\%$ & $\mathrm{n}$ & $\%$ \\
\hline Intestinal amoebiasis & 30 & 27 & 90 & 3 & 10 \\
\hline Liver abscess & 30 & 2 & 10 & 27 & 90 \\
\hline -Control patients & 50 & 50 & 100 & 0 & 0 \\
\hline Total & 110 & 80 & - & 30 & - \\
\hline
\end{tabular}

Table 2 - Results of the CIE test in the diagnosis of liver abscess, intestinal amoebiasis and persons witbout anoebic infection, in Colombia.

\begin{tabular}{|c|c|c|c|c|c|}
\hline \multirow{3}{*}{ Clinical form } & \multicolumn{5}{|c|}{ Results } \\
\hline & \multirow{2}{*}{$\begin{array}{l}\mathrm{Nr} \text { of } \\
\text { cases }\end{array}$} & \multicolumn{2}{|c|}{ negative } & \multicolumn{2}{|c|}{ positive } \\
\hline & & $n$ & $\%$ & $\mathrm{n}$ & $\%$ \\
\hline Intestinal amoebiasis & 30 & 30 & 1000 & 0.0 & 0.0 \\
\hline Liver abscess & 30 & 10 & 33.3 & 20.0 & 66.6 \\
\hline Control patients & 50 & 50 & 1000 & 0.0 & 0.0 \\
\hline Total & 100 & 90 & - & 20 & - \\
\hline
\end{tabular}

sensitivity for ELISA and CIE tests were 100\% and $66 \%$ respectively (Table 3 ). The specificity and the predictive value of positive tests with both reactions were 100\%. The predicitive value of negative test was 100\% for ELISA and $83 \%$ for CIE (Table 3).

\section{DISCUSSION}

In this study, we confirmed the clinical suspicion of extraintestinal amoebiasus by serological tests. Indeed, all cases of amoebic liver abscess could be detected by the presence of antibodies against $E$. histolytica by

Table 3 - Value of tarous tests according to the diagnosis

\begin{tabular}{|c|c|c|c|c|}
\hline \multirow{3}{*}{ Values } & \multicolumn{4}{|c|}{ Clinical form } \\
\hline & \multicolumn{2}{|c|}{$\mathrm{ALA}^{*}$} & \multicolumn{2}{|c|}{$1 \mathrm{~A}^{* *}$} \\
\hline & ELISA & CIE & ELISA & $\mathrm{CIE}$ \\
\hline Sensitivity & 90.0 & 66.7 & 10.0 & 0.0 \\
\hline Especificity & 100.0 & 100.0 & 100.0 & 100.0 \\
\hline Predictive value of positivite test & 100.0 & 100.0 & 100.0 & 100.0 \\
\hline Predictive value of negative test & 94.3 & 83.3 & 65.0 & 62.5 \\
\hline
\end{tabular}
$p<0.05$

- ALA = amoebic liver abscess

* IA = intestinal amoebiasis.

CIE and ELISA technique. Our results validate the use of these techniques as a tool in the diagnosis of invasive amoebiasis, e.g. amoebic liver abscess (ALA) $)^{7118}$
ELISA technique is very useful in determination of different serotypes of antibodies (IgG, IgM, IgE, IgA) in sera of patients infected by $E$. bistolytica as was 

comparison of enzyme-linked immunosorbent assay (ELISA) and counterimmunoelectrophoresis (CIE). Revista da Sociedade Brasileira de Medicina Tropical 29:27-32, jan-fev, 1996.

shown by Hock et al?. This method showed high sensitivity and specificity in those cases where the parasite was very invasive such as intestinal (dysentery) or liver amoebiasis. The ELISA was reliable compared with healthy controls.

Analyzing the ELISA results in the diagnosis of 30 patients with liver abscess, we found that only 3 patients were negative by this serological test. Reviewing these cases we concluded that two of the patients had liver abscesses secondary to stabbing injuries, which responded favorably to combined antimicrobial therapy (against gram positive, gram negative and anaerobic bacteria) and surgical drainage. The third patient did not respond to the anti-amoebic therapy, then a surgical drainage was performed and appropriate antibiotic treatment was indicated, since Staphylococcus aureus was isolated from the purulent material. Thus, the 3 patients who were negative by ELISA and CIE were also negative for amoebic liver abscess, and actually had a pyogenic liver abscess. On the other hand, 3 patients with intestinal amoebiasis and without liver abscess were positive by ELISA but negative by CIE. Although our study did not take in consideration the difference between dysenteric and acute form of intestinal amoebiasis, the seropositivity on ELISA test could indicate a tissseu invasion with $E$. bistolytica ${ }^{7}$. In fact, most of our patients without clinical evidence of liver abscess had a chronic form of intestinal amoebiasis.

The specificity of ELISA testing in the diagnosis of amoebic liver abscess was supported by the fact that amoebic antibodies were absent in serum from healthy controls 111214 . However some troubles may arise when the optical densitics are in the limit of the cut-off $(+1$ SD). Longitudinal studies are needed to asses the antibody responses variability along the evolution of the disease. This could also allow a beller therapeutical follow-up.

The CIE for detection of antiamoebic antibodies in the patients sera has been carried out and correlated with the routine dianostic microscopic examination of stools and pas samples from patients with a charascteristic clinical case. In the 30 patients with liver abscess evaluated by CIE test, 7 cases were negative. Those cases had clinical and ultrasonographic findings of liver abscess, of which just 3 were the patients mentioned above (non-amoebic liver abscess) and 4 cases were false-negative. These 4 patients did respond and improve after anti-amoebic treatment.

Our results are in agreement with of Bapat and Bhave $^{1}$, who found in 20 of 30 proved cases of ALA a seropositivity by CIE. Moreover, Samrejrongroj et a $1^{11}$ compared CIE and ELISA for $E$. bistolytica antibodies determination in patients with amoebiasis and reported a sensitivity of $93.5 \%$ and $100 \%$ respectively. Sathar et $\mathrm{al}^{12}$ evaluated the ELISA test for serodiagnosis of amoebic liver abscess, and found the presence of IgG antibodies with a sensitivity of $99 \%$. Similar results were obtained by Shetty er $\mathrm{al}^{1 \mathrm{1i}}$. Finally, Hock er al', comparing both tests found ELISA more sensitive than CIE $(97.4 \%$ vs $88.5 \%$ respectively). Altogether, these resutls show that ELISA is more sensitive than CIE: and that both tests are highly specific for amoebic liver abscess.

The gold standar for the diagnosis of ALA is the liver biopsy'. However this procedure is not currently done in every case. Otherwise, the percentage of positively for trofozoites in the amalysis of pus in the liver abscess is low. Therefore the $E$. bistolytica antibodies determination by ELISA is a good diagnostic tool in ALA, as a non-invasive and costeffectiveness procedure.

In conclusion, the diagnosis of liver amoebiasis in tropical countries can be attempted by the search of E. bistolytica antibodies by both ELISA and CIE techniques. Currently we are routinely using ELISA to confirm ALA diagnosis. This will allow us to study the seroprevalence as well as the reliability of this test in therapeutical followups. Other cases of liver abscess should be included (e.g. hydatid cyst, metastatic or hepatic carcinomas), as well as other parasitic diseases, in order to asses the possibility of cross-reaction with diseases clinically similar to extra-intestinal amoebiasis.

\section{RESUMO}

o abscesso bepático é a complicaçâo mais freqüente da amebiase intestinal: o seu diagnótico sugere-se pelo quadro clinico, mas é confirmado pelos estudos paraclinicos. Para confirmar o diagnóstico precisa-se identificar a $\mathrm{E}$. histolytica, o 
Restrepo MI, Restrepo Z, Villareal CLE, Aguirre A, Restrepo M. Diagnostic tests for amoebic liver abscess: comparison of enzyme-linked immunosorbent assay (ELISA) and counterimmunoelectropboresis (CIE). Retista da Sociedade Brasileira de Medicina Tropical 29:27-32, jan-fet, 1996

que é apenas possícel em muito poucos casos. As protas sorológicas melboram notadamente o diagnóstico das complicaçóes seleras da amebiase. Em nosso estudo comparamos o teste de ELISA e a Contraimunoeletroforese (CIE). Ambas as técnicas foram utilizadas para detectar anticonpos contra ameba em 50 pacientes sem amebiase, 30 pacientes com abscesso bepático e 30 com amebiase intestinal. rodos os soros dos pacientes sem amebiase foram negativos por ambas as técnicas. Quando analisamos os soros dos pacientes com amebiase intestinal, encontrou-se que $10 \%$ destes, foram positivos para ELISA, enquanto que nenbum o foi para CIE. Nos sorus dos pacientes com abscesso bepático, encontrou-se uma positividade de $90 \%$ para ELISA e $66.6 \%$ para CIE. Estes resultados mostram que o teste de ELISA foi de maior sensibilidade (100\% de sensibilidade) no diagnóstico do abscesso bepático amebiano. quando comparado com a Contraimunoeletroforese $(66.6 \%)$.

Palauras-chates: Abscesso bepático amebiano. Diagnóstico, ELISA. CIE

\section{ACKNOWLEDGMENTS}

We thanks Corporación para Investigaciones Biológicas (CIB), Instituto Colombiano de Medicina Tropical (ICMT), Medellín, Instituto Nacional de Salud (INS), in Bogotá and Universidad de los Ancies in Bogotá. We are also indebted to Carlos Berancur MD, Nelson Ramirez MD, Santiago Nicholls MD, Felipe Guhl PhD, Luz Acosta Lic and Rosalba Betancur Lic, for their interest and cooperation in this study.

\section{REFERENCES}

1. Bapat MM, Bhave GG. Counter immunoelectrophoresis in the immunodiagnosis of amoebiasis. Journal of Postgraduate Medicine 36:124-127, 1990.

2. Barnes PF, Cock KM, Reynolds TN, Ralls PW. A comparison of amebic and pyogenic abscess of the liver. Medicine (Baltimore) 66:472-483, 1987.

3. Botero D, Restrepo M. Parasitosis humanas. $2^{\text {a }}$ edição. CIB, Medellín, p.24-57, 1992.

4. Diamond LS, Harlow DR, Cunnick CC. A new medium for the axenic cultivation of Entamoeba bistolytica and other Entamoeba. Transaction of the Royal Society of Tropical Medicine and Hygiene 72:431-433, 1988.

5. Frey ChF, Zhu Y, Suzuki M, Isaji S. Liver abscess. Surgical Clinical of North America 69:259-271, 1989.
6. Ghandi BM, Irshad M, Chawla TC, Tandon BN. Amebic liver abscess and circulating immune complexes of Entamoeba bistolytica proteins. The American Journal of Tropical Medicine and Hygiene 39:440-444, 1988.

7. Hock GM, Foon KL, Chuen HL, Choo NG, Singh M. a comparison of the ELISA with other serological tests in the serodiagnosis of amoebiasis. Southeast Asian Journal Tropical Medicine and Public Health 20:399-405, 1989.

8. Mehlotra RK. Entamoeba bistolytica: from intestine to liver. Parasitology Today 4:235, 1988.

9. Riegelman RK, Hirsch RP. Cómo estudiar un estudio y probar una prueba: lectura crítica de la literatura médica. Organización Panamericana de la Salud. Publicación Científica n" 531, p.112-121, 1992.

10. Rustigi AK, Richter JM. Pyogenic and amebic liver abscess. Medical Clinic of North America 73:847857,1989 .

11. Samrejrongroj $P$, Tharavanij $S$. Assesment of validity of counterimmunoelectrophoresis and ELISA in the routine diagnosis of amoebiasis. Journal of Tropical Medicine and Public Health 16:365-370, 1985.

12. Sathar MA, Simjee AR, Nel JD, Bredenkamp BL, Gathiram V, Jackson TF. Evaluation of an enzymelinked immunosorbent assay in the serodiagnosis of amoebic liver abscess. South African Medical Journal 74:625-628, 1988

13. Sepulveda B, Aubanel M, Landa L, Velásquez G. Avances en la técnica de contra-immunoelectroforesis para el estudio serológico de la amibiasis. Archivos de Investigación Médica 3:363-370, 1972.

14. Shetty N, Nagpal S, Subba Rao PV, Schoroeder H. Detection of $\operatorname{IgG}, \operatorname{Ig} A$, IgM and $\operatorname{IgE}$ antibodies in invasive amoebiasis in endemic areas. Scandinavian Journal of Infectious Diseases 22:485-491, 1990.

15. Voller A, Bidwell DE, Bartlett A. Enzyme immunoassays in diagnostic medicine. Theory and practice. Bulletin of the World Health Organization 53:55-65, 1976.

16. Walsh JA. Problems in the recognition and diagnosis of amoebiasis: estimation of the global magnitude of morbidity and mortality. Reviews of Infectious Diseases 8:222-238, 1986.

17. World Health Organization Parasitic diseases. Council for International Organizations of Medical Sciences. International Nomenclature of 
Restrepo MI, Restrepo Z, Villareal CLE, Aguirre A, Restrepo M. Diagnostic tests for amoebic liver abscess: comparison of enzyme-linked immunosorbent assay (ELISA) and counterimmunoelectrophoresis (CIE). Revista da Sociedade Brasileira de Medicina Tropical 29:27-32, jan-fev, 1996.

Diseases. Geneve, World Health Organization, p.16-17, 1987.

18. Youssef FG, Mansour NS. Evaluation of enzymelinked immunosorbent assay (ELISA), indirect hemagglutination (IHA), counterimmunoelectrophoresis (CEIP) and immunodifusion (ID) in the serodiangosis of amebiasis. Journal of the Egyptian Society of Parasitology 18:373-381, 1988. 